\title{
High Proportion Renewable Energy Supply and Demand Structure Model in 2050
}

\author{
Xiaoxia Wei, Jie Liu, Tiezhong Wei, and Lirong Wang
}

\begin{abstract}
In considering of high proportion of renewable energy supply in $\mathbf{2 0 5 0}$, the accelerating of energy consumption gross, source and environment can affect the energy system restrict affection are stronger. Add wind and solar to electricity energy with large amount of energy source exploitation. The energy source amount per person is lower. Considering the renewable energy amount and supply, primary energy storage and structure problem is standing out. Before the wide spread of renewable energy, Using the high-carbon energy in China can pollute seriously. Chinese energy supply and demand problem is research key point. This paper researches Chinese energy supply and demand pattern system and evaluation methodology, gives out the inner and outer influencing elements. And evaluate Chinese energy supply and demand pattern from energy gross, structure, distribution and transportation. Use energy supply synthesize radar comparison chart in certain time period. From energy security, economy, clean and efficiency, analyze the benefit comparisons of Chinese energy supply and demand pattern. This energy supply and demand pattern model will give one certain theoretical analysis and practice reference to the further high proportion of renewable energy.
\end{abstract}

Key words-Benefit, high proportion of renewable energy supply, inner and outer element, power grid affection, supply and demand pattern.

\section{INTRODUCTION}

Energy is the fundamental of modern civilization. From all countries development practice, the speed and degree of country and regional economic development is depending on modern energy supply guarantee system's ability and construction. As the maximal developing country, China has gotten attract worldwide attention and it gotten the most support from the energy system development. Energy is one of the fundaments to guarantee Chinese national economy sustain, stabilization, sound development, which is also one of the implement comprehensively, coordinately, sustainably. So strength our country energy supply and demand scientific analysis, its advanced management theory method research, have quite strong reality backgrounds [1]-[4].

Energy supply and demand is the key topic, and it is confronting with new situation. High proportion of renewable energy supply is being considered in the ten to thirty years, which will also affect the Chinese electricity energy supply and structure.

1) In China, maybe until 2030, coal usage will be the

Manuscript received October 15, 2015; revised January 20, 2016.

Xiaoxia Wei is with the State Grid Energy Research Institute, Beijing, China (e-mail: 20583853@qq.com).

Jie Liu, Tiezhong Wei, and Lirong Wang are with Heilongjiang State Grid Company, Harbin, Heilongjiang, China (e-mail: 2571636115@qq.com, weixiaoxia@sgeri.sgcc.com.cn, $173099301 @$ qq.com). fundamental electricity energy in long period of time, the coal transportation and coal power layout optimization is much more impendency. Parts of coal producing area are approaching to the science capacity. The receiving port power source construction is extruding power transportation space. Make the coal and power have little configuration space.

2) In China, natural gas and its import scale expect have rapid growth; shale gas is changing the world using gas condition. Distribution energy sources are changing the world power configuration; also affect the power grid structure.

3) Renewable energy's economic development and efficient utilization are facing to be solved. In the further, the renewable energy will be accelerated to the power generation energy supply. But to the wind, the abandon wind is one extrude problem. The wind basement exploit is suffocated. Disperse exploit cannot support goal. While to the solar energy, the large occupation land and low utilization time will affect the renewable energy efficiency and economy.

4) International energy cooperation and global energy configuration promising are further infection. Energy consumption is approaching to the energy supply border. So it is needing to layout Chinese power supply economically, stabilization, reliably under the global vision. And China is giving the new theory to establish global energy connection.

This paper analyzed the energy supply's new circumstances and key problems. Make the energy supply and demand structure as key line of current situation and future situation. And make the research in different views [5], [6].

1) The assessment indicator system of energy supply and demand. Describe the energy supply pattern and its evolution. Evaluate the security, economy, clean and efficiency.

2) The evolution characteristics of our energy supply and demand pattern. Research the Chinese energy development under the analysis of the layout and project. And give out the long term energy changing pattern.

3) Research on the power grid function and affection to the energy supply and demand.

\section{INDICATOR SYSTEM OF ENERGY SUPPLY AND DEMAND} PATTERN

\section{A. Key Element of Energy Supply and Demand Pattern}

Energy supply and demand is meaning that, in one certain period of time, the whole country and different regions energy 
resource, producing, transportation, consumption, import and different energy in separating region balancing, trans-regional transportation condition. The evolution of energy supply and demand pattern is the track of different period of energy quality and quantity development. The key element of energy supply and demand pattern is gross, structure, distribution and transportation. And energy transportation includes variety, scale, direction and distance [7]-[9].

\section{B. Indicator System of Energy Supply and Demand Pattern}

Allocating the energy situation is one of important foundation to scientific judge energy management. But now this research area is lacking quantification description and evaluation method. Normally, it uses the perceptual knowledge and historical experience to judge energy distribution condition. And the analysis method is urgent technical problem. This paper gives the energy distribution affection evaluation indicator system, and carries out the demonstration evaluation. And strive to quantity and demonstrate energy distribution affection and breaking through.

Energy distribution affection and evaluation system include security, economy, clean and efficiency four aspects. And every aspect includes several support indexes. In order to embody power function to energy distribution, the support indexes include power sector and its index of correlation.

The support index and its choosing are following the authority theory, showed in Fig. 1. In the security evaluation aspect, the support indexes include energy reserves, foreign-trade dependence, coal railway transportation channel and its transportation use ration, coal-power transportation system reliability. In economic evaluation aspect, the support indexes include coal and coking industry and its ex-factory price indices of industrial product, oil and gas producer's price for manufactured products, fuel power purchase price indices, and power producer's price for manufactured products. In clean evaluation aspect, the support indexes include clean energy ration to primary energy consumption, sulfur dioxide discharge strength, sulfur dioxide discharge value, environmental pollution control investment ration to GDP, clean energy generate electricity ration and other indices. In the high effective aspect, the support indexes include energy loss per GDP, energy processing and transforming efficiency, power energy ration to terminal energy consumption [10]-[13].

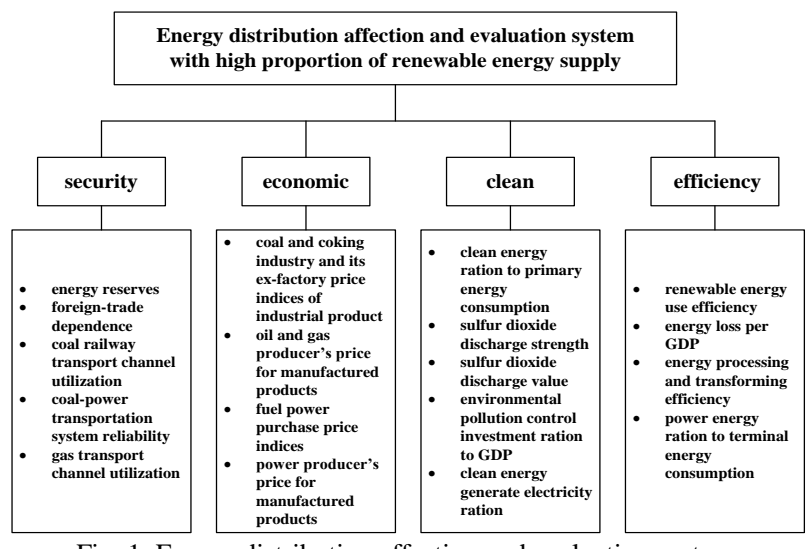

Fig. 1. Energy distribution affection and evaluation system.

\section{Evaluation Methodology of Energy Supply and Demand Pattern}

Energy distribution and affection evaluation can adopt the main element analysis method (PCA), through covariance matrix feature vector can reveal the common evolvement role, which can reach the index goal without considering man-made thinking.

The main element analysis (PCA) include three steps, the first step is construct the covariance matrix according to the random vector. The second step is solving the covariance value of matrix, and judge the contribution degree, confirming the main element. The third step is construct and solve the synthesize vectors using main element proper vector.

From Fig. 2, we can get one certain year as the base, made the base year's every prospect synthesize indexes evaluation score as ten points. Considering all aspects of synthesize indexes historical development and further trend, making the equal synthesize indexes to scale in one degree, get the historical and further degree evaluation description. This system adopts radar plot to descript the whole system synthesize evaluation and it can be viewed the relative development and changing trend from the line and scale.

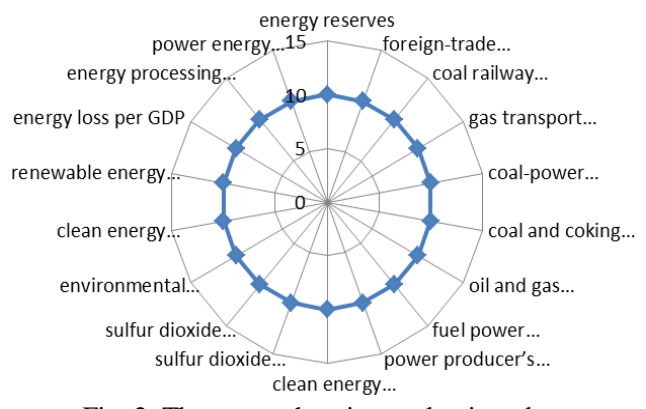

Fig. 2. The comprehensive evaluation plot.

\section{RELATIVE IMPORTANT PROBLEM OF CHINESE ENERGY DISTRIBUTION AND SUPPLY DEMAND}

Energy supply and demand pattern is one big and comprehensive system. This system has different aspects. The inner elements affect the outer elements. This research combines the pattern time and space changing analysis, through the energy different elements.

\section{A. Energy Supply and Demand Inner Element}

The inner elements of power supply and demand pattern include four parts. In this research, we consider coal, natural gas, water, nuclear, wind, solar and international power cooperation, showed in Table I. These parts are considering the power resources, supply ability, power consumption and transportation [14]-[18].

In China, the most popular energy resources are coal, natural gas and wind, to the solar energy, which is using in the distributed area now. The solar is the main energy in the further usage.

Coal is the most important energy to China. To the world coal, Chinese coal reserve is low and difficult to exploit. If we consider the resource amount, mining condition, environment, water resource, transportation and security, China coal maximum exploitation amount is 41 billion tons/year. From 
2009, Chinese coal import has increased $160 \%$, and becomes the No.1 of the importing coal countries. In the further, railway and water transport will enlarge the scale. China will spread its coal move from the west to the east, which can satisfy the need of the economy. Also consider the Ultra-high voltage power grid, it can also increase the coal usage ratio.

TABLE I: THE INNER ELEMENT OF POWER SUPPLY AND DEMAND PATTERN

\begin{tabular}{|c|c|}
\hline \multirow{5}{*}{ Coal } & sustainable supply ability \\
\hline & coal transportation ability \\
\hline & coal to power transportation ratio \\
\hline & coal power distribution space \\
\hline & water resource supply ability \\
\hline \multirow{2}{*}{ Natural gas } & supply and demand trend \\
\hline & gas generation type \\
\hline \multirow{2}{*}{ Water } & Supply and demand and in 2035 to saturation \\
\hline & Pumped-hydro energy storage regulation \\
\hline nuclear & Stable development with conservatism \\
\hline \multirow{2}{*}{ Wind } & development model and choose \\
\hline & programmer target and distribution \\
\hline \multirow{2}{*}{ Solar } & development model and choose \\
\hline & programmer target and distribution \\
\hline \multirow{3}{*}{$\begin{array}{l}\text { International } \\
\text { power } \\
\text { cooperation }\end{array}$} & resource around of surrounding countries \\
\hline & $\begin{array}{l}\text { developing potential of international energy } \\
\text { basement }\end{array}$ \\
\hline & prospect cooperation of international power \\
\hline
\end{tabular}

Natural gas importing and producing are accelerating rapidly. It is changing the energy consumption condition. In china, natural gas can be imported through gas loop and LNG, from 2010 to 2014, the natural gas transportation is reaching 1370 billion steres, gas pipeline is 4.4 ten thousand kilometers, reserve gas ability is 210 billion steres/year. Big gas power generation and distribution gas system is the main type of gas usage. And from the using type, the distribution is most effective. From the cost of generation, the combined cycle is lowest. From the savage of generation, single loop has the fast adjustment.

Water is influenced by weather and season condition, according to the survey and draw data, chinses water installed capacity will be saturation in 2035. Then part of water installed capacity will be the basis capacity of the power supply. Pumped-hydro energy storage will be peak load regulation.

Nuclear is the restricted energy in certain period of exploitation time, China is focusing on its serious affection to human and environment, and its will be basis energy capacity.

Wind generation is facing two key problems, one is abandon wind and the other is lack of fund. Actually, in china, we have several different wind exploitation and usage methods, such as basement plus local consumption, distribution exploitation, basement plus combine output and basement plus wind as the main output. Wind generation is most popular energy usage in china; we adopt demand side management, power adjustment, optimize power operation and strengthen the output passage way to increase the wind energy consumption.

Solar generation will be the main renewable energy in the next thirty year, it has wide power supply. Now it is transforming into the thermoelectricity.

International power cooperation of China is near to the Russia, Mongolia, Kazakhstan and other countries, which have wide spread area and plenty of source can be used by China. Russia has plenty of coal, oil and natural gas reserves. Mongolia has coal, wind, solar reserves. Kazakhstan has amount of fossil energy. In the further, China will make high voltage transmission to transport energy, which will reduce the discharging and energy import [19], [20].

\section{B. Energy Supply and Demand Outer Element}

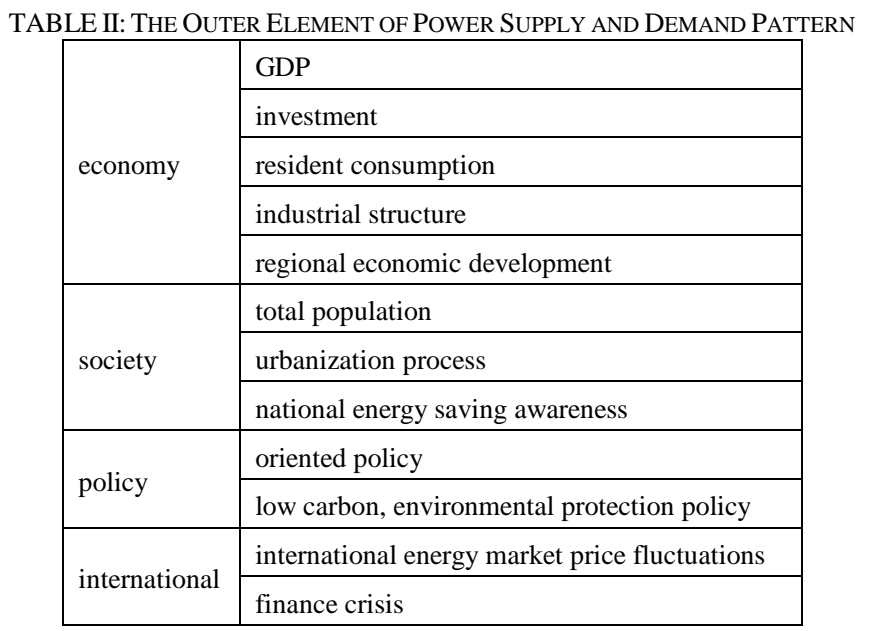

Economy affects energy usage, and imposing the energy development. Energy usage guarantees Chinese long-term of economy accreting. At the same time, Chinese fast economy increasing is the main impetus. To the investment, energy consumption and investment have opposite direction, the investment and its policy will affect the energy usage. The industrial structure and household consumption can determine the energy demand structure, with the industrial structure adjustment, the synthesize indexes will be changed, which can determine the regional economy development. In the further, the east part of China is still the most develop part and its energy consumption will be ahead, showed in Table II.

Society part includes population gross, urbanization and whole people energy saving consciousness. Energy consumption has positive relation with population gross, changes the usage type. The urban is the main energy consumption places.

Policy part includes guidance quality and low carbon environmental protection property. The energy strategy in China is now focusing on energy management, reserve, market competition and clean energy development, which are very important to country energy strategy. The constraint, inducing and stimulating policies are inducing the further energy development and its trend. The low carbon and environmental policy can also improve and enhance energy consumption structure.

International part includes energy market fluctuations price and finance crisis. From the world energy market view, the low energy price can affect the produce profit and less the replacement chasing trend. The high price will accelerate the industry producing cost and salesmen price, and it will affect the energy consumption. The finance crisis will also push the real economy, lead to its recession, reduce the energy 
demand.

\section{PREDICTION OF ENERGY SUPPLY AND DEMAND PATTERN EVOLUTION TREND IN 2020}

\section{A. Energy Gross Evolution}

In the further, Chinese energy power consumption demand will accelerate fast. The 12th Five-Year Plan, the annual average increases $5.0 \%$, The 13th Five-Year Plan, the average will be $3.4 \%$ in prediction.

The power consumption demand is synchronized with energy consumption demand. At the same time, with the fast development of renewable energy, power is standing out in energy system consumption demand; the power consumption speed increase is faster than energy consumption speed.

\section{B. Energy Structural Evolution}

1) With the fast acceleration of energy supply structure and its clean adjustment, natural gas and non-fossil energy and power ration has fast acceleration.

From the primary energy consumption structure, coal consumption to energy consumption gross proportion will be $57 \%$ in 2020 , and its decreasing amplitude is $12 \%$. Natural gas consumption ratio will accelerate $9 \%$ until 2020. The non-fossil energy ration will reach to $15 \%$ in 2020 . The renewable energy of electricity power generation to primary energy will be nearly to $80 \%$.

From the power installation structure, coal installation ration will reduce to $54.1 \%$ in 2020 . The gas power generation installation ratio is $5.7 \%$ in 2020 . The clean installation ratio will reach to $40 \%$.

2) Energy supply structure will have obvious diversification trend, in the further; energy supply will combine with civil fossil energy, civil clean energy and foreign import in China.

In statistics from 2010 to 2020, China's new primary energy consumption is 16.6 billion tons standard coal. Chinese fossil energy newly increased supply is 16.1 billion tons standard coal. And the newly increased clean energy supply is 4.4 billion tons standard coal. The foreign import newly increase energy supply is 6.1 billion tons standard coal.

3) Energy distribution electrification degree will increase; power is the prominent in energy distribution.

From the energy conversion, non-fossil energy is mainly be transformed into electricity power. Power generation energy ratio to primary energy is rapid increasing fast. In 2020, power generation energy ratio to primary energy is $50 \%$.

\section{Energy Distribution Evolution}

In the further, the energy distribution intensification in China will be increased fast, big-scale energy basement to energy production gross will also accelerate.

In 2020, Chinese coal production is most spread in the north parts, such as Shanxi, Shanxi, Neimeng and Xinjiang. The production mount will be 27 billion tons. The oil spreads in north-east, north-west oil production areas. Natural gas spreads in south-west and north-west energy basement. The newly accelerating hydro-power is in south-west basement. And wind installment will be in tri-north parts of China. The nuclear power is spreading in east part.
In 2020, Chinese big synthesize energy basement production ratio to whole primary energy production is $73 \%$.

\section{Energy Transportation Evolution}

In China, energy transportation harmonization degree will improve rapid, which will form the reasonable division of labor and complement each other's advantage, and form one energy synthesize system.

Railway capacity and coal transportation scale is matching. In 2020, Chinese tri-west parts railway outward transport coal is about 12 billion tons. The use ration is $60 \%$ and ample is big enough, which can fit the coal transport seasonal fluctuation and outward changing.

The highway coal transport will be controlled in reasonable degree. In the further ten years, china can take place of the coal highway transportation about 2 billion tons, railway transportation about 1 billion tons.

China will form coal-power energy transportation combination system. In 2020, from the Chinese energy basements outward transport, power transportation will reach $23 \%$, railway coal transportation will be $72 \%$, highway coal transportation will 5\%. That will form the reasonable division of labor and complement each other's advantage energy transportation system. And the power grid will have great impact to wind and hydro-power output.

\section{EVAluation OF ChINESE ENERGY SUPPly PATTERN EVOLUTION TO 2050}

From the security, economy, clean and efficiency, evaluate energy supply pattern evaluation trend. The result showed that the security, clean and efficiency will be promoted rapidly, and the clean is outstanding. Consider the clean energy development and its environmental benefit; the transportation structure will be adjusted. Then the distribution economic degree will be promoted.

\section{A. From 2020 to 2050 Installed Capacity}

According to the energy development prediction, Chinese renewable energy will be $80 \%$ to the primary energy in 2050 . The fossil energy will be the fundamental load. Wind and solar will be the electricity power supply. From 2020 to 2050, showed in Fig. 3, the renewable energy will take place of most part of the fossil energy. The coal capacity will be 78669 kilo watt; wind capacity will reach to 120000 kilo watt; solar capacity will be 150000 kilo watt.

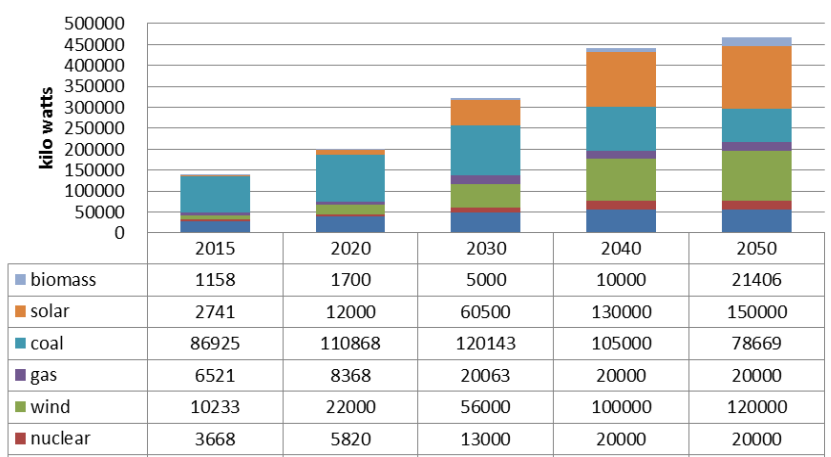

Fig. 3. Energy capacity prediction from 2015 to 2050

From Fig. 4, from 2015 to 2050, the proprotion of 
renewable energy to primary energy is accelerating from $10 \%$ to $77.1 \%$. The proprotion of renewable energy electric quantity to gross generation is from $21.7 \%$ to $83.2 \%$. The proprotion of generation energy to primary energy is from $46.4 \%$ to $92.7 \%$. The proprotion of electric energy to terminal is from $25.6 \%$ to $67.4 \%$.

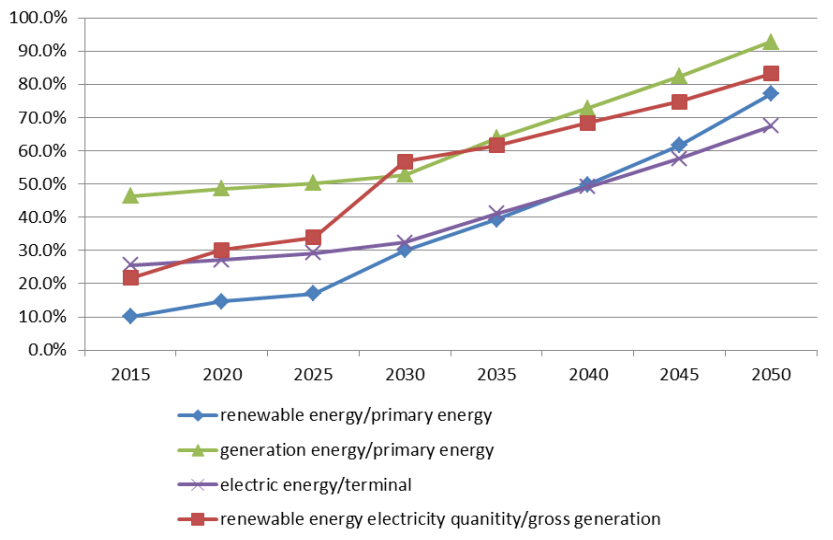

Fig. 4. Energy proportion comparison from 2015 to 2050.

\section{B. Analysis of Energy Supply Pattern Evolution Trend}

Make the 2014 as the basic year; analyze the 2020 to 2050 per ten-year as period which can get four series dates. In the energy distribution, economy, clean, efficiency elements are increasing in the further, and the security is getting weak because of renewable energy volatility.

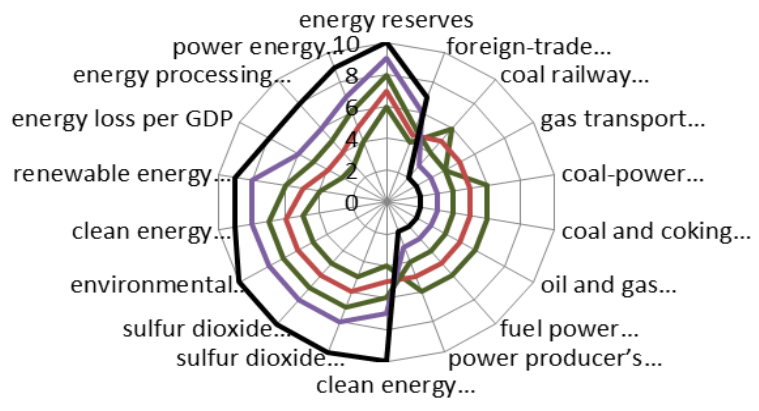

$$
-2014-2020-2030-2040-2050
$$

Fig. 5. Energy supply pattern evolution trend from 2020 to 2050.

From Fig. 5, the decline of security is mainly because of sufficient railway, import risk coefficient decline, energy diversification degree increment. The improvement of economy is mainly because of environment benefit accelerating, considering the green GDP conception and its economical efficiency. The improvement of clean is mainly because of non-fossil energy ratio increase, and pollution emissions strengthen losing. The improvement of efficiency is mainly because of energy loss per GDP, energy consumption elastic coefficient decline and electricity to terminal power consumption ratio increasing.

\section{POWER GRID IMPACT TO ENERGY DEVELOPMENT AND SUPPLY PATTERN}

In China, the power grid function has four aspects in new development. (1) Satisfy energy and power large scale long distance transportation. (2) Satisfy receiving areas multiple energy high efficient integration and coordinated operation. (3) Satisfy new energy development and new type power-using service needing. (4) Satisfy the power market platform material base needing. In the further, power grid will be pivotal role in energy exploit, transform, transportation, consumption, security, service and market trading system.

1) Satisfy energy and power large scale long distance transportation. China is still in industrialization, informatization, urbanization and agricultural modernization rapid development stage. The power demand will continue to increase. The east and midland will restrain as the power load center in long period of time, while the new coal power, hydro-power, wind and solar power are mainly in the west and north areas. Power demanding and generation is reverse. Long-distance, large-scale energy transportation is the most important characteristic in Chinese energy supply pattern evolution. Chinese west power transport to east and north power transport to south will be still. The energy basement of hydro-power in south-west, coal power in west and north, wind in tri-north and solar in west, will be transported to east and mil-part of china. Russia, Mongolia, Central Asia and Southeast Asia will transport power to China. Grid will be the most important part Chinese energy synthesize transportation system. As improvement of coal power optimization and distribution, the clean non-fossil energy will be transported in large scale and long distance, which will be very important toe Chinese energy power large scale transportation in energy synthesize system.

2) Satisfy receiving areas multiple energy high efficient integration and coordinated operation. With power trans-regional scale rapid improvement, the development region will have large ratio import power. Power system comprehensive degree will accelerate. The importing of coal power, hydro-power, reproducible energy and locale coal power, gas power, hydro-power, storage power, nuclear power, reproducible energy combine into coordination system, and it requires high demanding, such as big area, strong grid, dynamic balance and security high level.

3) Satisfy new energy development and new type power-using service needing. Wind power, solar power and other new energies have randomness and intermittent characteristics. Their controllability and predictability is lower than original fossil power generation. Large scale exploitation will bring big challenge of power grid control and coordination. So the power grid is needing advanced automatics, coordination control and storage technique to implement the new energy accuracy control and high efficient utilization. At the same time, with the wide spread of electric car and electric household appliance, the energy quantity will face the higher requirement. Intelligentize will be the further needing of grid.

4) Satisfy the power market platform material base needing. The whole country power market platform operation needs whole power grid connection, which can carry out the fundamental effect of larger degree, wider scale to give play to energy source distribution. Promote the 
non-fossil energy large scale exploitation usage and make larger economic benefit, power save benefit, source environmental benefit, security benefit and social benefit. In order to adapt the big change of power grid function, the further power grid must be strong and intelligent. With the breaking through of high voltage transportation, intelligent power grid construction can be carry forward synchronization. And it will form high voltage as the center, all or different levels harmonious development forming intelligent grid.

In China, energy development carries out production and consumption concentration ratio reaching to high level, energy producing and consumption showing reverse distribution, trans-regional demand reaching long distance. And these characteristics will change energy distribution configuration, coal-transport cooperation, propel intelligent grid construction, drive energy structure adjustment and energy development changing, realize energy security, economy and clean.

\section{A. Energy Supply Security}

Promote clean energy consumption and fuel oil replacement, which can decline foreign-trade dependence. In 2020, electric car will replace fuel oil 700 million tons. In 2050 , electric car will totally replace the traditional vehicles.

Promote energy transportation system diversified development, reduce transportation risk, and accelerate energy security level. In 2020, the basements will get coal to transportation ratio is $4: 1$. In 2050 , the reliability of coal transportation will be $1: 1$, showed in Table III.

TABLE III: GRID EFFECT OF POWER SECURITY SUPPLY

\begin{tabular}{|c|c|c|c|c|}
\hline classify & & 2015 & 2020 & 2050 \\
\hline \multirow{3}{*}{ Security } & \multirow{2}{*}{$\begin{array}{l}\text { foreign-trade } \\
\text { dependence }\end{array}$} & $\begin{array}{l}\text { limit of } \\
\text { electric car } \\
\text { scale }\end{array}$ & $\begin{array}{l}\text { Electric car } \\
\text { ownership is } 500 \\
\text { millio, replace } \\
\text { fuel oil } 700 \\
\text { million tons. }\end{array}$ & $\begin{array}{l}\text { Electric car } \\
\text { totally } \\
\text { replacement }\end{array}$ \\
\hline & & $\begin{array}{l}\text { limit of } \\
\text { trans-regio } \\
\mathrm{n} \text { of power } \\
\text { energy } \\
\text { volume } \\
\text { exchange }\end{array}$ & $\begin{array}{l}\text { Rapid improve } \\
\text { grid construction, } \\
\text { replace coal } \\
\text { importing } 5000 \\
\text { million tons. }\end{array}$ & $\begin{array}{l}\text { None coal } \\
\text { importing }\end{array}$ \\
\hline & $\begin{array}{l}\text { Reliability of } \\
\text { coal-transpor } \\
\text {-tation }\end{array}$ & $3: 1$ & $4: 1$ & $1: 1$ \\
\hline
\end{tabular}

\section{B. Energy Clean Development}

TABLE IV: GRID EFFECT OF POWER CLEAN SUPPLY

\begin{tabular}{|c|l|l|l|l|}
\multicolumn{5}{|c}{ TABLE IV: GRID EFFECT OF POWER CLEAN SUPPL } \\
\hline classify & \multicolumn{1}{|c|}{2015} & \multicolumn{1}{|c|}{2020} & 2050 \\
\hline \multirow{4}{*}{ clean } & $\begin{array}{l}\text { Ratio of clean } \\
\text { energy to } \\
\text { primary } \\
\text { energy } \\
\text { consumption }\end{array}$ & $\begin{array}{l}\text { Ratio of clean } \\
\text { energy to } \\
\text { primary energy } \\
\text { is 9\% }\end{array}$ & $\begin{array}{l}\text { Ratio of clean } \\
\text { energy to primary } \\
\text { energy is 15\% }\end{array}$ & $\begin{array}{l}\text { Ratio of } \\
\text { clean energy } \\
\text { to primary } \\
\text { energy is } \\
77 \%\end{array}$ \\
\cline { 2 - 5 } & $\begin{array}{l}\text { sulfure } \\
\text { dioxide } \\
\text { emission }\end{array}$ & $\begin{array}{l}\text { Changjiang area } \\
\text { is 45 tons }\end{array}$ & $\begin{array}{l}\text { Changjiang area } \\
\text { is 75 tons }\end{array}$ & none \\
\hline
\end{tabular}

Promote clean energy consumption. In 2020, trans-region power contribution degree to clean energy consumption is $27 \%$, and in 2050 , the ration will reach to $77 \%$.

Reduce pollution emission of development area. In 2020, the sulfure dioxide is 75 million tongs/year. And to 2050, the dioxide emission will be zero, showed in Table IV.

\section{Energy Distribution Efficiency}

Promote the power transportation and clean energy usage efficiency. In 2020, trans-regional power can lack abandoning abandon water and electricity is 320 billion kilowatt-hours, ratio of trans-regional wind power to total power is $40 \%$. In 2050, generation energy to primary energy is $92 \%$

Promote ratio power to terminal energy consumption. In 2020 , generating power ratio to primary energy consumption will accelerate $8.2 \%$, and in 2050 , the ratio will be $67.4 \%$, showed in Table V.

TABLE V: GRID EFFECT OF POWER EFFICIENCY SUPPLY

\begin{tabular}{|c|c|c|c|c|}
\hline Classify & & 2015 & 2020 & 2050 \\
\hline \multirow{3}{*}{ Efficiency } & \multirow[b]{2}{*}{$\begin{array}{l}\text { Energy } \\
\text { process } \\
\text { transition }\end{array}$} & $\begin{array}{l}\text { line loss rate } \\
6.5 \%\end{array}$ & $\begin{array}{l}\text { Line loss rate } 6.2 \% \text {, } \\
\text { Power appliance } \\
\text { usage ratio will be } \\
\text { accelerating }\end{array}$ & $\begin{array}{l}\text { Generation } \\
\text { energy to } \\
\text { primary } \\
\text { energy is } \\
92 \%\end{array}$ \\
\hline & & $\begin{array}{l}\text { Clean energy } \\
\text { has little } \\
\text { trans-regional } \\
\text { exchanging } \\
\text { power, the } \\
\text { north abandon } \\
\text { wind ratio is } \\
\text { exceeding } \\
20 \% \text {. }\end{array}$ & $\begin{array}{l}\text { Less the } \\
\text { hydro-power in } \\
\text { southwest is } 320 \\
\text { billion } \\
\text { kilowatt-hour, } \\
\text { reduce the abandon } \\
\text { wind power is } \\
\text { billion } \\
\text { kilowatt-hour. }\end{array}$ & $\begin{array}{l}\text { Hydro-power } \\
\text { is stable, and } \\
\text { wind power } \\
\text { can be stored }\end{array}$ \\
\hline & $\begin{array}{l}\text { Power } \\
\text { ratio to } \\
\text { terminal } \\
\text { energy }\end{array}$ & $20.9 \%$ & $27.5 \%$ & $67.4 \%$ \\
\hline
\end{tabular}

\section{Energy System Economy}

In 2020, trans-regional power can save cost 670 billion yuan/year. From the green GDP, it will reduce whole country environmental loss 30 billion yuan/year. In 2050, with high proportion of renewable energy connecting to the power system, we do not needing to accelerate the environment investment, showed in Table VI.

TABLE VI: GRID EFFECT OF POWER ECONOM Y SUPPLY

\begin{tabular}{|l|l|l|l|l|}
\hline classify & & 2015 & 2020 & 2050 \\
\hline \multirow{2}{*}{ economy } & $\begin{array}{l}\text { Power } \\
\text { industrial } \\
\text { products } \\
\text { ex-factory } \\
\text { price }\end{array}$ & $\begin{array}{l}\text { coal } \\
\text { transportation to } \\
\text { receiving port } \\
\text { generating } \\
\text { power has low } \\
\text { economy }\end{array}$ & $\begin{array}{l}\text { Save the cost of } \\
\text { generating power } \\
\text { cost is 450 billion } \\
\text { yuan }\end{array}$ & $\begin{array}{l}\text { Renewable } \\
\text { energy } \\
\text { replacement }\end{array}$ \\
\cline { 2 - 5 } & Green GDP & $\begin{array}{l}\text { No space in } \\
\text { development }\end{array}$ & $\begin{array}{l}\text { Lack environment } \\
\text { loss is 30 billion } \\
\text { yuan /year }\end{array}$ & $\begin{array}{l}\text { No needing } \\
\text { to add } \\
\text { investment }\end{array}$ \\
\hline
\end{tabular}




\section{CONCLUSION}

Energy is the most important to country development and the speed and degree of country and regional economic development is depending on modern energy supply guarantee system's ability and construction. This paper researches Chinese energy supply and demand pattern system and evaluation methodology with high proportion of renewable energy supply, gives out the inner and outer influencing elements. And evaluate Chinese energy supply and demand pattern from energy gross, structure, distribution and transportation. Give the energy supply synthesize radar comparison chart in certain time period. From the energy security, economy, clean and efficiency, analyze the benefit comparisons of Chinese energy supply and demand pattern. This energy supply and demand pattern model will give one certain theoretical analysis and practice reference.

\section{REFERENCES}

[1] H. Sarak and A. Satman, "The degree-day method to estimate the residential heating natural gas consumption in Turkey: A case study," Energy, vol. 28, no. 9, pp. 929-939, 2003.

[2] R. Balaehandra and Chandru, "Modelling electricity demand with representative load curves," Energy, vol. 24, no. 3, pp. 219-230, 1999.

[3] A. Kumar and S. Bhattacharya, "Greenhouse gas mitigation potential of biomass energy technologies in Vietnam using the long range energy alternative," Energy, vol. 28, no. 7, pp. 627-654, 2003.

[4] R. M. Mackay and S. D. Probert, "Forecasting the United Kingdom's supplies and demands for fluid fossil-fliels," Applied Energy, vol. 69, no. 3, pp. 161-189, 2001.

[5] S. Messner and L. Schrattenholzer, "Message-Macroo: Linking an energy supply model with a macroeconomic module and solving it iteratively," Energy, vol. 25, no. 3, pp. 267-282, 2000.

[6] V. S. Ediger and H. Tatlidil, "Forecasting the Primary energy demand in Turkey and analysis of cyclic patters," Energy Conversion and Management, vol. 43, no. 4, pp. 473-487, 2002.

[7] J. Cuaresma et al., "Forecasting electricity spot-prices using linear univariate time-series models," Applied Energy, vol. 77, no. 1, pp 87-106, 2004.

[8] D. P. Sharma, N. P. S. Chandramohanan, and R. Balasubramanian, "Demand for commercial energy in the state of Kerala, India: An econometric analysis with medium-range projections," Energy Policy, vol. 30, no. 9, pp. 781-791, 2002.

[9] A. J. Persaud and U. Kumar, "An eclectic approach in energy forecasting: a case of Natural Resources Canada's (NRCans) oil and gas outlook," Energy Policy, vol. 29, no. 4, pp. 303-313, 2001.

[10] L. C. H. Chow, "A study of sectoral energy consumption in Hong Kong (1984-97) with special emphasis on the household sector," Energy Policy, vol. 29, no. 13, pp. 1099-1110, 2001.

[11] J. Bentzen and T. Engsted, "A revival of the autoregressive distributed lag model in estimating energy demand relationships," Energy, vol. 26, no. 1 , pp. 45-55, 2001.

[12] D. Finon, "Un modele energetique pour la France," Paris: Centre National de la Recherche Scienti-Fique, 1976.

[13] E. van der Voot, "The EFOM 12C energy supply model with in the EC modeling system," Omega, vol. 10, no. 5, pp. 507-523, 1982.

[14] M. N. Eltony and N. H. Al-Mutairi, "Demand for gaspoline in Kuwait: An empirical analysis using cointegration techniques," Energy Economies, vol. 17, no. 3, pp. 249-253, 1995.

[15] R. Ramanathan, "Short-and long-run elasticities of gasoline demand in India: An empirical analysis using cointegration techniques," Energy Economies, vol. 21, no. 4, pp. 321-330, 1999.

[16] R. Samimi, "Road transport energy demand in Australia: A cointegration approach," Energy Economics, vol. 17, no. 4, pp. 329-339, 1995.

[17] A. Bentzen and T. Engsted, "A revival of the autoregressive distributed lag model in estimating energy demand relationships," Energy, vol. 26, no. 1 , pp. $45-55,2001$

[18] Wa. Oh and K. Lee, "Energy consumption and economic growth in Korea; testing the causality relation," Journal of Energy Modeling, vol. 26, no. 8-9, pp. 973-985, 2004.

[19] G. Hondroyiannis, "Estimating residential demand for electricity in Greece," Energy Economies, vol. 26, no. 3, pp. 319-334, 2004.

[20] K. H. Ghali and M. I. T. EI-Mutairi, "Energy use and output growth in Canada: a multivariate cointegration analysis," Energy Economies, vol. 26, no. 2, pp. 225-238, 2004

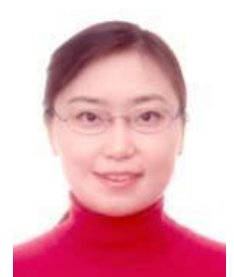

system planning.
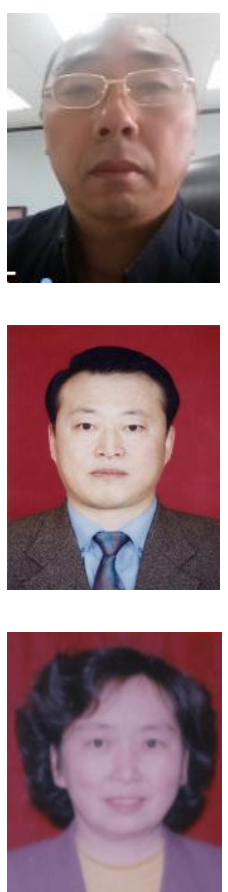

Xiaoxia Wei was born on march 26, 1980, she has a post-doctor of power system and its automation with the State Grid Energy Research Institute, Beijing, China.

She works in the energy research field, and mainly focusing on the power system plan, power energy research, environment economy and energy economy. She had published 30 EI indexed paper and relative reports, such as Chinese energy planning and power

Jie Liu was born on January 1, 1961, he has a master degree in communication, he is with Heilongjiang State Grid Company, Harbin, Heilongjiang Province, China.

He works in the energy research field, and mainly focusing on the power system plan, power energy research, environment economy and energy economy.

Tiezhong Wei was born on March 9, 1951, he has a master degree in communication, he is now with Heilongjiang state grid company, Harbin, Heilongjiang Province, China.

He works in the energy research field, and mainly focusing on the power system plan, power energy research, environment economy and energy economy.

Lirong Wang was born on September 21, 1952. She has a master degree in communication, she is now with Heilongjiang State Grid Company, Harbin, Heilongjiang Province, China.

She works in the energy research field, and mainly focusing on the power system plan, power energy research, environment economy and energy economy. 